\title{
The Role of Heritage Planning in Dark Sites Case Study: Tsunami Sites in Banda Aceh
}

\author{
${ }^{*}$ Zya Dyena Meutia, ${ }^{2}$ Arief Rosyidie, ${ }^{3}$ Denny Zulkaidi, and ${ }^{4}$ Sri Maryati \\ ${ }^{*}$ Bandung Institute of Technology, Indonesia, dyenameutia@yahoo.com \\ ${ }^{* 2}$ Bandung Institute of Technology, Indonesia, ariefr@pl.itb.ac.id \\ ${ }^{* 3}$ Bandung Institute of Technology, Indonesia, dennyz@pl.itb.ac.id \\ ${ }^{* 3}$ Bandung Institute of Technology, Indonesia, smaryati@pl.itb.ac.id
}

\section{Submitted: $14 / 08 / 2020$ Revised: $31 / 10 / 2020 \quad$ Accepted: $21 / 11 / 2020$}

How to cite this article: Meutia, Z. D., Rosyidie, A., Zulkaidi, D. \& Maryati, S. (2020). The role of heritage planning in dark sites case study: Tsunami Sites in Banda Aceh. IJELR: International Journal of Education, Language, and Religion, 2(2), 64-76. http://doi.org/10.35308/ijelr.v2i2.2492

\begin{abstract}
The concept of dark heritage has been used as a concept of preserving an area or site that contains relics due to dark events in the past. Tsunami disaster in 2004 that hit Banda Aceh as the most affected area after the disaster has left various relics that need a consideration regarding to dark heritage planning. However, in the planning of dark heritage, it has not yet considered aspects of local communities, especially survivors as the most affected group from the tsunami. The purpose of this paper is to observe the planning of dark heritage involving the community as an important aspect in the preservation of post-disaster areas and to find out the components and values that are considered important by the community in preserving dark heritage. The study was conducted from August 2019 to January 2020 in the post-disaster area, Banda Aceh, as the most affected area using a qualitative approach, a case study. This study showed that dark heritage planning which involves the community is strongly influenced by communicative values in building agreements in the post-disaster memorial area to create sustainable dark heritage planning. Field research also found that spatial elements need to be considered in planning post-disaster dark heritage in seeing post-disaster areas as areas of dark heritage that are also influenced by religious values by the community treating dark heritage sites.
\end{abstract}

\section{Keywords}

dark heritage; planning; post disaster; communicative; religious

\section{Introduction}

Heritage has became an important issue on urban development that must be paid attention to people, places and policies in urban planning (Unesco Global Report, 2016). Heritage planning approach is needed to create an inclusive, safe, peaceful and resilient community by integrating elements of local 
wisdom in a place and culture (ICOMOS, 2016; Goal 11.4). In determining and preserving heritages, it is necessary to consider the values inherent in objects and sites thought to be heritages with values of virtues (positive characteristics) (Ashworth Graham, 1999; Martokusumo, 2016). Heritage planning is a part of urban planning that is very concerned about human aspects (Ashworth Graham, 1999). However, heritage planning is often technocratic and ignores the voices of local people who have values in viewing heritage (Jokilehto and Bryne, 2001).

Planning as a discipline and practice can be described as future-oriented human activities. Forward orientation is associated with prescription or forecasting actions that characterize planning. To prescribe, it is necessary to select the elements of the past that are used as input in the analysis of existing conditions (Friedmann, 1987). Planning can also be explained as a process undertaken to change the future in accordance with expectations (Abbot, 2005). The relationships of past, present, and future situations are continuous components of one another. These three components are prerequisites that must be mastered by planners, to shape a better future (Myers \& Kitsuse, 2000 in Abbot, 2005).

However, current planning is still oriented on the physical aspect, the concept of urban planning with the concept of heritage can be used as another option in finding solutions to the inclusion of the human dimension in solving various problems in this uncertain era. One example is the problem of disasters related to cultural heritage. There have been many dark tragedies in both natural and social disasters in the last few decades (UNHCR, 2018; World Bank, 2018a). Natural and social disasters have the potential to destroy an area and also produce relics (remnants of a disaster) (Megan Good, 2016; Rico, 2014). The relic needs to be preserved as a commemoration and study and planning of urban development after a disaster by building memorials and museums (Rico, 2016; Dewi, 2016). The theory known for preserving an area or site that contains relics or historic buildings resulting from dark events is known as dark heritage (Logan and Reeves, 2009; Stone, 2011). Planning relics, buildings, monuments and sensitive areas need to consider the values of dark heritage.

The concept of dark heritage has increased attractions in recent years in the field of archeology and heritage studies more broadly (Logan and Reeves, 2009; Stone, 2011). The concept of dark heritage refers to places associated with death, suffering and disaster even war, concentration camps or sites of disaster crime such as Chernobyl disaster. There are several terms that are closely related to dark heritage, namely difficult heritage, contested heritage, dissonant heritage and negative heritage. These terms are often raised in the discourse of heritage studies recently and the most popular is the concept of dark heritage related to dark events.

Disaster is one of the factors forming heritage (Rico, 2014; Leuwens, 2011) as has been studied from various experts who are included in the saujana heritage, cultural heritage and a combination of saujana heritage and culture. Therefore, disasters are important to be associated with damage studies because the world has entered an era of uncertainty and natural disasters are occurring more frequently, especially large risks to disasters that are very difficult to predict such as earthquakes, and tsunamis as effect after the earthquake. Based on this incident, this study aims to find out how dark heritage planning involves human aspects, e.g. people living in post-disaster areas? What values are considered important by the community in planning dark heritage and how is the public's perception of seeing dark heritage in post-disaster areas and what is the meaning of the memorial of dark heritage for the local community?

\section{Dark Sites as Heritage}

Heritage is a result of social and cultural construction rather than just accepting past values (McClelland et al, 2013), whereas dark heritage is a concept similar to a painful heritage, difficult heritage, a cruel heritage and places that are full of suffering and shame (McClelland et al, 2013). Dark 
heritage sites are places and institutions that stand as legacies for painful periods in history; genocide massacres and sites, places of association for former criminal institutions, chaos in prisons, conflicts, wars, natural disasters and many more (McClelland et al, 2013). Management / governance of dark heritage sites is a structured activity that is supported by full meaning and overall experience for visitors in a variety of contexts and complex problems (McClelland et al, 2013).

In the literature review, many have discussed the heritage from time to time (Jokilehto, 1999; Smith, 2006; Vecco, 2010; Blake, 2015). Heritage tends to be a product of the past that is considered as a good character and positive value. There have been many heritage studies but very few have discussed the dark heritage as a painful heritage. Whereas in practice and the phenomenon has been many memorials, sites, buildings and traditions related to dark events used as dark heritage, but discussion about dark heritage is still little in the literature, especially about post-disaster dark heritage planning because now we have entered an era filled with uncertainty. Therefore, it is clearly needed to do research on dark heritage planning to be a learning and reminder for future generations.

Heritage is objects, buildings, sites, places or other physical aspects of the past viewed in the present. Smith (2006), one of the heritage experts whose theories are widely used in the world states that things become heritage because there is a cultural process to remember the past referring to intangible objects that give meaning and value to them so that they become heritages, such as social and cultural practices. In Byrne's (1991) thought, archaeological objects or sites become meaningful to humans and result from actions or performance to pay attention to objects and heritage sites. Humans value artifacts and justify the reasons why they chose the site as valuable from the past (Graham, 2002, p.250-251; Harvey, 2001; Munjeri, 2004).

The real meaning of the inheritance is something that is not all possessed from the past, but the real event of the inheritance when human emotions and personal feelings become a unified whole in sharing and remembering moments, events that are owned by others (Smith, 2006). In the view of David Harvey's (2001) the term heritage is a "verb", heritage is not something physical but rather an act that involves humans emotionally and connects with the past of an object or site that has meaning and value which of course can be different for each individual in evaluating it. In Europe, heritages have traditionally been found as tangible objects or physical forms such as buildings, artifacts, archeological sites and memorials. This is because since the 19th century heritages were strongly influenced by the views of Europeans especially the government and the elite (Byrne, 1991; Harvey, 2001; Smith, 2006). This perspective emphasizes the sound that heritages are material and are always physical forms that can be mapped, regulated, maintained and greatly affect the way people perceive what is called heritage now (Smith, 2006).

The opposite of positive heritage is "difficult histories", sites of conscience, dark heritage, dissonant heritage. Negative heritage deals with sites that are preserved due to dark events. There are various cons assume that dark heritage is not a true heritage because it contains negative values, rejection and want to be forgotten. Dark heritage is stigmatized by sites of crime, tragic or traumatic events that are interpreted as shared losses by self-identified groups or communities (Seaton, 2011). Heritages are also always associated with legalization, ownership, a product that was present deliberately developed in response to current demands and shaped by current requirements.

\section{Method}

This research is categorized in qualitative research with a case study. Case studies are in-depth investigations of a single person, group, event or community. Typically, data are gathered from a variety of sources and by using several different methods (e.g. observations \& interviews). The data of 
this study were sourced from primer and secondary data. Data processing is done by data classification, analysis, personal observation and field survey.

\section{Location and Time of Research}

Banda Aceh is one of the areas in Aceh Province that was hit by an earthquake with 8.9 Ritcher scale and tsunami waves with an estimated height of 10-20 meters. The disaster has caused most of the city area that is $60 \%$ of $61 \mathrm{~km}^{2}$ Banda Aceh City area (Kenny et al, 2010). Meuraxa area is the area that most severely affected by the 2004 earthquake and tsunami and has a number of important histories in previous periods so that it has experienced various layers of value excellence that must be explored again to be preserved. The case chosen is a case that provides several reasons for knowledge. In studying heritage as a cultural tool in the process of heritage and remembrance / commemoration in the context of post-disaster, seeing that heritage has significantly changed before and after this natural disaster and produces new places. This case study is also located in Southeast Asia which represents an understanding of the damage from non-western cultures (Jokilehto, 1999).

\section{Dimensions of Dark Sites Heritage in Banda Aceh}

Dark heritage is considered because it has valuable values for future preservation. This includes significant objects of architecture, archeology and the knowledge and technology of a particular culture. Intangible heritage refers to the expression of life and tradition that innumerable groups and world societies have been passed down from their ancestors to convey / transmit knowledge to their children and grandchildren and most in oral terms namely storytelling / narration. Studies provide examples of both teraha (tangible) and intangible heritage. Examples of tangible dark heritage phenomena in museums are artifacts related to war and death. Dark intangible heritage involves ritual descriptions for funerals and how nuns care for sick people. Dark heritage refers to difficult heritage, places that are full of suffering, pain and shame, painful heritage and cruel heritage (McClelland et al, 2013). Dark heritage sites represent painful periods in history such as eras related to genocide, war, natural disasters and terrible prisons (McClelland et al, 2013).

The dimension of dark heritage in the post-disaster context in this case study refers to the post-tsunami natural legacy such as floating PLTD ships, mass graves, surviving mosques, surviving houses and memorials, former hospital ruins, tsunami museums, Blang Padang field and monuments.

Table 2 Types of dark sites heritage memorials in case studies

\begin{tabular}{ll}
\hline \multicolumn{1}{c}{ Object and region } & \multicolumn{1}{c}{ Description } \\
\hline $\begin{array}{l}\text { Floating PLTD } \\
\text { Ship }\end{array}$ & $\begin{array}{l}\text { Ship that was dragged by the tsunami as far as } 4 \mathrm{~km} \text { hit a } \\
\text { densely populated settlement and has been designated a } \\
\text { memorial / tourist attraction }\end{array}$ \\
\hline Mass Graves & The number of funerals for tsunami victims \\
\hline Mosques & The only building in the post-disaster area that survived intact \\
\hline Surviving House & One of the houses used as a tsunami memorial \\
\hline The Former & $\begin{array}{l}\text { The memorial was abandoned by the former second-largest } \\
\text { hospital in Banda Aceh }\end{array}$ \\
\hline Bospital Ruins & $\begin{array}{l}\text { A city square in Banda Aceh, which has claimed many lives } \\
\text { and has been designed as a memorial park }\end{array}$ \\
\hline Museum Tsunami & The largest tsunami memorial museum in the world \\
\hline Waves Monument & Tsunami reminder monument \\
\hline
\end{tabular}




\section{Document Analysis and Personal Observation}

It has been 14 years since the earthquake and tsunami devastated that the earth's Serambi Mekkah and left a deep melancholy. Banda Aceh is one of the cities hit hardest by Tsunami in 2004 and was one of the biggest disasters in the 21st century. This disaster in Aceh caused human loss of up to 180,000 lives while there were around 250,000 houses destroyed and razed to the ground and around 500,000 people become homeless and displaced (Kenny, 2010). This disaster has also changed the layout of the urban landscape in Banda Aceh and left many remnants in the form of debris, artifacts and sites that emerged after the tsunami disaster, such as the floating PLTD ship monument, mass burial areas, ships on top of residents' homes, Meuraxa Hospital, the mosque area that survived the tsunami and many others.

\section{Results and Discussion}

Heritage of post-disaster has the ability to support the anticipation of future loss in recurrent geological and climatic phenomena, gaining an active role in the construction of social and cultural resilience and as a tool of social wellbeing (Daly P and Rahmayati Y, 2012). However, most of the emphasis on heritage conservation approaches in post-disaster contexts throughout conservation initiatives, educational programs, local and international standards is included in the documentation, evaluation and remediation of heritage sources as historical sources, which are in line with the preservation of existing resources independently and may even overtake each actual or potential damage documented.

The initial survey was conducted before conducting interviews, field surveys recorded potential elements to obtain value and noted the meaning of survivors for the object. The thing that needs to be considered in this survey is the importance of obtaining overall perception of survivors, not only concentrating on the perceptions of only certain groups and objects of single elements.

Table 1: Summary of Data

\begin{tabular}{|c|c|c|c|c|c|}
\hline \multirow[t]{2}{*}{ Item } & Mosque & Big Ship & Ship Above & Outside & Total \\
\hline & Baiturrahim & PLTD & Lampulo House & Sites & Interview \\
\hline \multicolumn{6}{|l|}{ Sex } \\
\hline Male & 5 & 7 & 5 & 6 & 23 \\
\hline Female & 8 & 8 & 5 & 6 & 27 \\
\hline Total & 13 & 15 & 10 & 12 & 50 \\
\hline \multicolumn{6}{|l|}{ Age } \\
\hline $25-34$ & 1 & 5 & 2 & 2 & 10 \\
\hline $35-44$ & 7 & 5 & 3 & 3 & 18 \\
\hline $45-54$ & 8 & 4 & 2 & 4 & 18 \\
\hline $55-64$ & 2 & 0 & 0 & 2 & 4 \\
\hline \multicolumn{6}{|c|}{ Place of Residence } \\
\hline Banda Aceh & 10 & 13 & 12 & 5 & 45 \\
\hline Within Aceh & 2 & 2 & 1 & 0 & 5 \\
\hline
\end{tabular}




\section{Intangible Dark Heritage Theme}

Informant 1 stated that "religious values are very important in remembering the disaster as a reprimand from God"

Informant 4 stated that "sad memory value of seeing a mass grave recollected by a lost family"

Informant 15 stated that "the value of learning and awareness of disaster mitigation to be better prepared in facing disasters and can be used as a good tradition and culture"

Informant 9 stated that "religious-cultural values cannot be separated from each other because it is an important aspect in treating dark heritage sites"

\section{Tangible Dark Heritage Theme}

Informant 3 stated that "the value of age is not a major consideration in determining and preserving heritage"

Informant 10 stated that "the aesthetic value remains important in preserving heritage because it visually affects the behavior of people who preserve it"

Informant 13 stated that "the value of authenticity does not apply if an area and building is totally or partially destroyed but remains a memory for the community"

Theme Community perception of the post-tsunami Dark heritage site

Informant 5 stated that "The impact on the local community has become popular and many visitors come, for visitors to the existence of this historical site can be a reminder for the 2004 tsunami disaster. Activities around the object are only in the form of a visit or tour. It would be better in its design to have a playground for children, so that children are interested in having a look around.

Informant 7 stated that "For me personally there is no significant impact from the existence of this historical attraction. "

Informant 14 stated that "For me the souvenir seller for the existence of this tourist attraction is very important, namely as an income for my family's economy from selling souvenirs. I certainly strongly agree, given that there have been very few community visits lately, I hope this improvement can increase visits to this region. I think the people here all have bad memories with the object of this ship, the tsunami disaster.

The community stated that that preservation had only been managed by the government and rarely involved the community from the beginning of the heritage planning. This causes the community to conserve by means and local practices that they believe in. Many of them are carrying out religious rituals, traditional ceremonies to remember and take lessons even there are people who are traumatized and want to forget the incident by not wanting to preserve the dark heritage sites.

\section{Discussion}

\section{Preservation of Tsunami Sites as Cultural Heritage}

Normatively according to the Cultural Heritage Law No. 10 of 2011, regulations regarding cultural heritage in Indonesia are too standard where criteria for being a cultural heritage must be at least 50 
years old, representing the shortest possible 50-year age period, having special meaning for history, science, education, religion, and / or culture, and has cultural values for strengthening the nation's personality. Then, if we capture the reality in the example of the post-disaster destruction case that leaves ruins of artifacts, sites and areas related to their age and period of style, then cannot they be designated as cultural heritage? Which style can represent an area designated as a cultural preservation? Does the community agree with the current physical forms and how is the public's perception of seeing and treating them?

Questions like these make people become excited and come back to remember how important these places are to be preserved by being re-functioned with various activities, used for public interest and social learning for the future. There is new knowledge arising from the tsunami disaster where the remnants of the disaster are a reminder, commemoration and awareness of the community to rebuild the city, disaster reduction efforts with changes in landscape settings such as mangroves planted by the citizens together with the government, knowledge of evacuation routes save themselves if there are natural signs of a disaster and the use of buildings affected by the tsunami as a forum for discussion and meetings between residents.

Cultural heritage or often known as heritage is a cultural heritage that is passed on from generation to the next generation so that its preservation is maintained. heritages can be seen in physical and nonphysical forms of artifacts, buildings or historic areas along with the entire arrangement of objects in them. Heritage can also be a way of life, traditions, views / paradigms, customs preserved from generation to the next generation in a society. As an example related to the tsunami disaster that the Simeulue community has a tradition called Smong as a tradition that shows vigilance and runs to the hills in the event of an earthquake and other natural signs. Therefore, when the devastating disaster of 2004 occurred, many Simeulue people survived because they ran to the hills to save themselves and their families.

\section{From Rebuilding Better to Reconnecting with Past Cultures}

The Acehneses are very aware that their places, traditions, lifestyles, habits, norms have changed and some have disappeared through significant changes in the physical and symbolic aspects of the tsunami disaster. In addition to the physical aspects that serve as reminders, knowledge emerges in the invisible values, which are actually a more important aspect in building awareness to reduce disaster risks and deal with disasters at any time, as social learning is passed on to the future and spiritual values that make society more get closer to God (Meutia, 2017). The case in Banda Aceh shows that new knowledge emerged from the tsunami where the remnants of the disaster became a reminder, a commemoration and full awareness to rebuild the city, efforts to reduce disasters by changing landscape settings such as mangroves replanted by residents together with the government, knowledge of evacuation routes save themselves if there are natural signs of a disaster and the use of buildings affected by the tsunami as a forum for discussion and meetings between residents.

The earthquake occurred in Aceh not only happened once in 2004, historical evidence from folklore to archeological evidence can be traced in Aceh. The names Ie Beuna, Smong, Glogor and even Alon Buluek are names known as big waves after the earthquake which the Japanese called the tsunami. The mention of the name Pasie Karam for the name of the old city of Meulaboh, the site of the kingdom of Lamuri, even in the village of Meunasah Lhok, Lhong sub-district encountered by the Cave of Leting Ek which recorded the traces of the tsunami from ancient times to 2004 is very strong evidence that the tsunami hit Aceh not just once.

Conservation efforts at the regional and provincial levels have been carried out, but often fail to encourage the public to appreciate their meaning. Preservation efforts that have been carried out have not been sufficient to display the cultural image of a historic area. It is time, the local government 
focuses on establishing and conserving tsunami sites by involving the participation of local communities. In addition, tsunami heritage trail planning is needed to form a single entity (Meutia, 2018).

\section{Heritage Planning In Tsunami Dark Sites}

In post-disaster areas, the attachment of places in tangible and intangible forms is closely related to spatial planning in an area and needs to consider the values that underlie a dark heritage plan to be sustainable. There is no study that discussed this matter where the public can understand the dark heritage more deeply and comprehensively especially the benefits for urban planning. In post-disaster cities, memorial monuments can be a potential for creating city resilience (Vale and Campanella 2005: 344). This idea shows that the value of resilience is important for the public in viewing the memorial sites of the monument that are strongly suspected as dark heritage. Some words, however, are more difficult to classify into light or dark dimensions. For example, the word preservation for some informants might be associated with light or dark dimensions. The dark side of preservation of postdisaster heritage refers to public perceptions, especially survivors of the memorial of dark heritage because of feelings of suffering, trauma, sadness, pain and bad memory, while the bright dimension refers to hopes and goals / vision for a better life in the future.

The Acehnese are very aware that their places, traditions, lifestyles, habits, norms have changed and some have disappeared through significant changes in the physical and symbolic aspects of the tsunami disaster. In addition to the physical aspects that serve as reminders, knowledge emerges in the invisible values, which actually becomes a more important aspect in building awareness to reduce disaster risks and face disasters at any time, as social learning is passed down to the future and religious-cultural values create people get closer to God through the traditions and habits of everyday life in treating dark heritage sites.

The case in Banda Aceh showed that new knowledge emerged from the tsunami where the remnants of the disaster became a reminder, a commemoration and full awareness to rebuild the city, efforts to reduce disasters by changing landscape settings such as mangroves replanted by residents together with the government, knowledge of evacuation routes save themselves if there are natural signs of a disaster and the use of buildings affected by the tsunami as a forum for discussion and meetings between residents.

Conservation efforts at the regional and provincial levels have been carried out, but often fail to encourage the public to appreciate their meaning. Preservation efforts that have been carried out have not been sufficient to display the cultural image of a historic area. It is time, the local government focuses on establishing and conserving tsunami sites by involving the participation of local communities. In addition, tsunami heritage trail planning is needed to form a unified whole as a commemoration for the public. These sites and places are part of the order of everyday social life that guides the community from the elements of its historic landscape as one of trauma recovery. The people in Aceh need to be well acquainted with all post-tsunami sites and sites that they consider important to evoke memories, and be able to organize a better future.

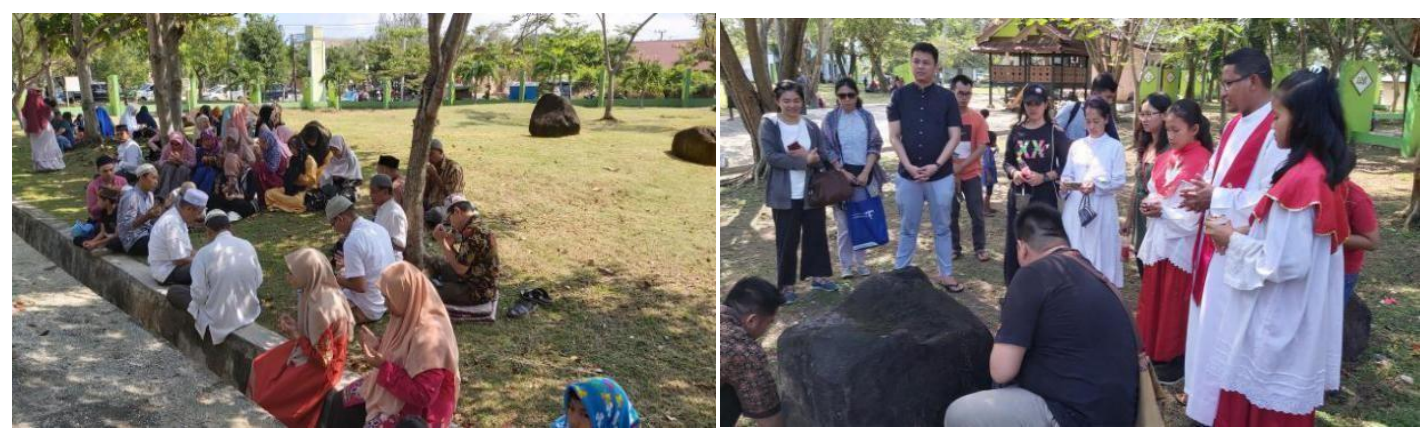


Figure 1 The writer visited the mass grave on Tsunami Disaster warning on December 26, 2019. It was seen that the community was praying and carrying out rituals according to their respective religions

At this mass grave site, not only Acehnese people visited the dark heritage site, but local and national visitors also prayed on this site. On December 26, everyone gathered to commemorate even tourists coming from abroad, namely Japan, China America, from Europe and Malaysia to pray at the tsunami disaster warning on December 26 each year. From observations it can be observed that religiouscultural values are highly considered in the planning of dark heritage sites because people see and treat dark heritage memorial sites with their respective ritual traditions and beliefs. Religion and culture here become important as the recovery of communities affected by the tsunami (Martokusumo, W. dan Zulkaidi, D. (2015)).

The literature presented above and community perceptions about case studies show that a value approach to planning a sustainable dark heritage is important and is a consideration for creating a quality, contextual and inclusive environment. The determination of the values and meanings of artifacts, objects, sites and areas to be preserved needs to reflect people's perceptions and interpretations as users / owners. Now, the concept of society also changes not only the residents, but also includes commuters, tourists, and so on. Related to the determination of the boundaries of the conserved area, it is not only determined by physical boundaries, but also exceeds that there are intangible values that are inscribed in the hearts and experiences of each member of the community. With the dynamics and unique local context (local value), the mechanism of planning for heritage sites or dark heritage sites can respond to ambivalence and realize the sustainability of urban heritage in the context of long-term development.

From a critical understanding of urban heritages, the existence of a place or an area in an urban setting even though a post-disaster area located in an urban setting can illustrate the formation of layers of excellence which are a series of long process outcomes as a matrix of cultural, religious, age, resilient values, memory and natural elements. This is actually nothing but the construction of the cultural heritage itself that is formed when people treat the memorial of dark heritage sites in their own way. For this reason, identification of significant values is needed so that the preparation of concepts can be measured. The heritage values approach must be rethought to concentrate on the relationship between the community and the region for the sustainability of the urban environment. Heritage material both tangible and intangible can be an expression united as an urban heritage work as a continuation of the past for the future.

In this study, the informants who were directly affected by the disaster emphasized the value of memory, religion, tradition and learning as significant values forming heritage. Whereas informants who are not directly affected by the disaster even have tourists emphasizing that the value of age, authenticity, integrity and aesthetics is no longer the main thing in determining the dark heritage site because when affected by a disaster, the remaining sites, areas, buildings, monuments, artifacts or even reconstruction can lead to a sense of place that inspires the sense and interest of informants to preserve it. However, there are several informants who state that aesthetics as a visual form are important to influence people's behavior in preserving heritage because so far heritage is synonymous with beauty and goodness.

The partially analyzed field observations data show that people are aware that their places, traditions, lifestyles, habits, norms have changed and some have disappeared through significant changes in the physical and symbolic aspects of the tsunami disaster. The most important indicators of authenticity are not materials such as the understanding of the western world but rather experiences, memories that are remembered by the public, activities and sense of place that are narrated in the form of texts or 
monumental works. In addition to the physical aspects that are reminders, knowledge in intangible values emerges, which becomes a more important aspect in building awareness to reduce disaster risks and face disasters in the future, as social learning is passed on to the future and spiritual values that make people more closer to God. From people's perceptions obtained through research related to the understanding dominated by the western world is not very precise in this context and is different from the considerations of experts. Although the physical forms have changed their authenticity, there are still functions related to the values in society that continue to run for the sustainability of the city.

This research presents a conceptual understanding of dark heritage planning and significant values as considerations in establishing and preserving heritage. There are many values that we can learn from the post-disaster case, which are closely related to the formation of heritages (objects, sites and regions) and teraga (cultural heritage, communication, social learning, local knowledge and so on). These values are very useful for the practice of urban heritage planning to understand the constellation of places that appear after a disaster because they are meaningful so that they can also build a cultural heritage of the community such as changing traditions, lifestyles towards a better direction without forgetting history. The sites and places that emerge are part of the fabric of daily social life not only to be seen but to function with a variety of positive activities, giving people access to a better life. Many sites and objects in this context actively play an important role in creating important everyday social functions, such as providing space for community deliberation, conflict resolution and decision making, disaster mitigation learning all of which are very fundamental to the process of urban sustainable development.

In this study it was found that people's perceptions of heritage-forming values place more emphasis on intangible values such as memory values, sense of place values, spiritual values and traditional values as a form of learning by remembering major events manifested in physical forms in post-disaster area. During this time, heritages are often considered to be old-fashioned, old, of aesthetic value and also maintained their authenticity and integrity. However, the case in the post-disaster area of Banda Aceh shows that the community, whether directly affected by the disaster or not, has a concern in preserving post-disaster heritage in the form of floating PLTD ship monuments, mosque areas that were not destroyed during the tsunami and mass graves by preserving significant values attached to it. Research conducted is still in its early stages and requires a higher validity value. To get high reliability, the number of respondents needs to be increased with a greater diversity of respondents.

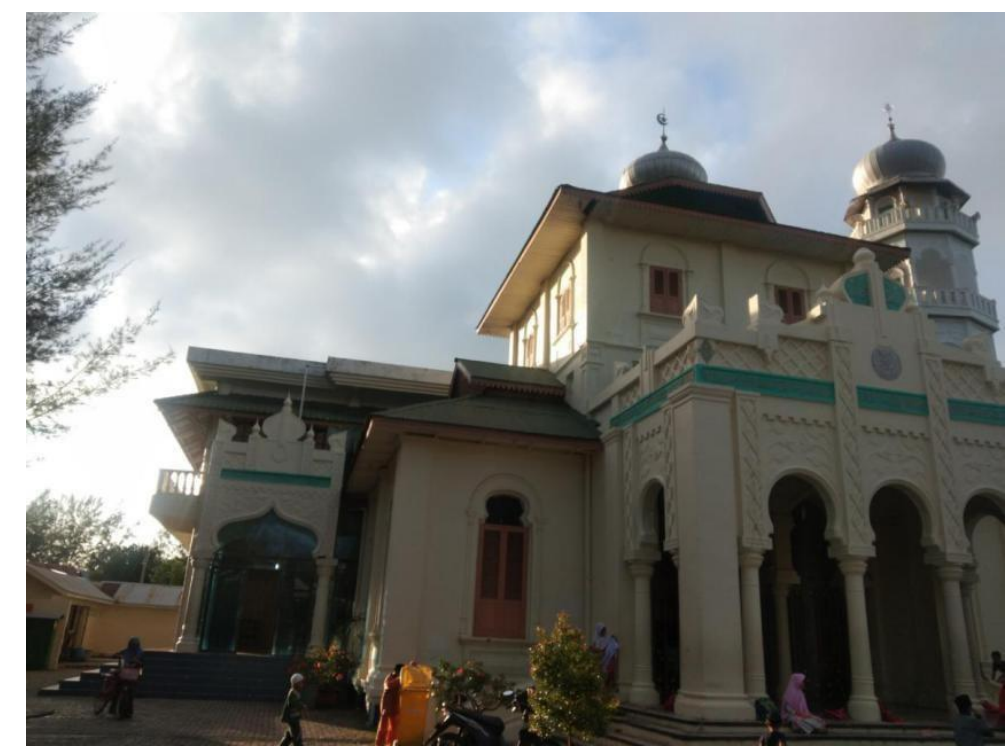

Figure 2. Baiturrahim Mosque, One of the relics of the 2004 Tsunami was the Floating PLTD Ship 
On December $26^{\text {th }}, 2004$, a giant wave as high as 21 meters hit the northern coast of Banda Aceh. The Ulee Lheue area, which is located right on the seashore, is one of the hardest hit areas. Almost all buildings in this area have been flattened or washed away by waves towards the center of Banda Aceh City - along with thousands of victims. When the tsunami struck, the mosque remained firmly standing in the middle of a stretch of debris surrounding buildings that have been destroyed. Only a small portion of the building was damaged by the disaster. Mosques are still standing strong not only as a building to save tsunami survivors but also a symbol of community resilience in the aftermath of the tsunami. Many people see mosques that survive among the many ruins of buildings as a sign that the tsunami has been given by God.

\section{Conclusion}

This study showed that dark heritage planning which involves the community is strongly influenced by communicative values in building agreements in the post-disaster memorial area to create sustainable dark heritage planning. Field research also found that spatial elements need to be considered in planning post-disaster dark heritage in seeing post-disaster areas as areas of dark heritage that are also influenced by religious values by the community treating dark heritage sites. Many sites in the urban landscape in Aceh that were affected by the tsunami actively played an important role in making everyday social functions, such as providing public space for community deliberations, resolving conflicts and making decisions. Interestingly, in the Acehnese understanding of the dark heritage or termed a dark heritage caused by the tsunami disaster, there is an extraordinary mix of cultural, historical and religious elements. This is not surprising given the level of religious observance in Aceh which has become more formalized by the application of sharia, making it relevant if tsunami sites become Islamic memorials for future learning. Tsunami sites play a simultaneous role as unifying religious identities, and as spaces where discussion is needed for reconstruction and urban development.

\section{References}

Ashworth ,G J. (1999) Heritage Planning: Conservation as the Management of Urban Change. Groningen (The Netherlands: Geo Pers).

Blake, J. (2002). Developing a New Standard-setting Instrument for the Safeguarding of Intangible Cultural Heritage. Elements for consideration. revised edition. Paris: UNESCO.

Byrne, D. (2009). A Critique of Unfeeling Heritage In: L. Smith and N.Akagawa (Eds.) Intangible Heritage (London: Routledge).

Daly P and Rahmayati Y. (2012) cultural heritage and community recovery in Post-Tsunami Aceh In From the Ground Up: Perspective on Post-Tsunami and Post-Conflict Aceh edited by Daly P, Feener R M and Reid A 57-78 (Singapore: ISEAS Publishing).

Dewi, C. (2017). "Rethinking Architectural Heritage Conservation in Post-Disaster Context." International Journal of Heritage Studies 23 (1): 1-14. Doi:10.1080/13527258.2017.1300927.

Friedmann, J. (1987). Planning in Public Domain: From Knowledge to Action, Princeton University Press.

Good, M. (2016). Shaping Japan's disaster heritage. The creation of new monuments and the preservation of ruins in the aftermath of the Great East Japan Earthquake and Tsunami. In A. 
Matsuda \& L. Mengoni (Eds.), Reconsidering Cultural Heritage in East Asia (pp. 1-23). London: Ubiquity Press.

Harvey, D. (2001): Heritage Pasts and Heritage Presents: Temporality, Meaning and the Scope of Heritage Studies. International Journal of Heritage Studies, 7 (4), 319-338.

HABITAT III. (2016). Urban Culture and Heritage United Nations Conf. on Housing and Sustainable Urban Development 17 to 20 October Quito Ecuador

ICOMOS. (2016). The Principles for the Conservation of Heritage Sites in the World

Jokilehto, J.(1999): A Historyof Architectural Conservation. Oxford: Butterworth Heinemann.

Kenny, S. (2010). Reconstruction through Participatory Practice? In Clarke M, Fanany I and Kenny S Post-Disaster Reconstruction: Lessons Learn from Aceh. (London: Earthscan, Ltd).

Leeuwen,R.v .(2011). A Touch of Tragedy : Pre- and Post Tsunami Symbolism in Banda Aceh, Indonesia. In P. J. M. Nas (Ed.), Cities Full of Symbols: A Theory of Urban Space and Culture Leiden: Leiden University Press.

Logan, W \& Reeves, K. (2009). Places of Pain and Shame : Dealing with Difficult Heritage. London : Routledge.

Meutia, Akbar and Zulkaidi. (2018). Heritage planning and rethinking the meaning and values of designating heritage sites in a post-disaster context: The case of Aceh, Indonesia. In IOP Conference Series: Earth and Environmental Science Vol.158.

Martokusumo, W. and Zulkaidi, D. (2015): Some notes on area-based conservation: Lesson learned from Bandung, International Journal Of Built Environment And Sustainability, Faculty of Built Environment, Universiti Teknologi Malaysia, 2(2), 125-130.

McClelland, et al. (2013): A values based approach to heritage planning: raising awareness of the dark side of destruction and conservation. Liverpool University Press. DOI: 10.38.28/tpr.2013.31.

Martokusumo W (2015). Arsitektur dan Pelestarian: Menuju Pengelolaan Berkelanjutan Bangunan dan Lingkungan Cagar Budaya [Architecture and Conservation: Towards a Sustainable Management of Buildings and Cultural Heritage Sites] Orasi Ilmiah Forum Guru Besar ITB 25 September 2015.

Munjeri, D. (2004). Tangible and Intangible Heritage: from Difference to Convergence. Museum International, 56(1»2), 12»19.

Rico, T. (2014). "The Limits of a 'Heritage at Risk' Framework: The Construction of Post-Disaster Cultural Heritage in Banda Aceh, Indonesia.” Journal of Social Archaeology 14 (2): 157-176. doi:10.1177/1469605314527192.

Rico, T. (2016). Constructing Destruction: Heritage Narratives in the Tsunami City. UCL Institute of Archaeology Critical Cultural Heritage Series 12. New York and London: Routledge.

Seaton, A. V. (Eds.). (2011). Slavery, contested heritage and thanatourism. Binghampton: Haworth Hospitality Press.

Smith, L. (2006). Uses of Heritage. New York, NY: Routledge.

Stone, P. and Sharpley, R. (2011) Consuming dark tourism: a thanatological perspective. Annals of TourismResearch 35(2), 574-595. DOI: 10.1016/j.annals.2008.02.003.

The Cultural Heritage Law No. 10 of 2011. 
Unesco Global Report. (2016). Global education monitoring report: Place: inclusive and sustainable cities.

UNHCR. (2018). Global Trends Report-UNHCR.

Vale, L. J., \& Campanella, T. J. (Eds.). (2005). The Resilient City: How Modern Cities Recover from Disaster New York: Oxford University Press.

Vecco, Marilena. (2010). A definition of cultural heritage : From the tangible to the intangible. Journal of cultural heritage, 321-324.

World Bank. (2018a). The world Bank Annual Report.

Z D Meutia. (2017). Built urban heritage conservation in Islamic societies: Study case in Banda Aceh, Indonesia. IOP Conf. Ser : Earth Environ. Sci. 70012066. 